Newfoundland and Labrador Studies

\title{
A voyage to Newfoundland "for the reformation of abuses in that Country and upon the coasts thereof": A letter in the family papers of Sir Henry Salusbury, drafted by Richard Whitbourne (?)
}

Ryan Lewis, Peter E. Pope et Tor Fosnæs

Volume 33, numéro 2, 2018

URI : https://id.erudit.org/iderudit/1058081ar

DOI : https://doi.org/10.7202/1058081ar

Aller au sommaire du numéro

\section{Éditeur(s)}

Faculty of Arts, Memorial University

ISSN

1719-1726 (imprimé)

1715-1430 (numérique)

Découvrir la revue

Citer ce document

Lewis, R., Pope, P. \& Fosnæs, T. (2018). A voyage to Newfoundland "for the reformation of abuses in that Country and upon the coasts thereof": A letter in the family papers of Sir Henry Salusbury, drafted by Richard Whitbourne (?). Newfoundland and Labrador Studies, 33(2). https://doi.org/10.7202/1058081ar 


\section{A voyage to Newfoundland "for the reformation of abuses in that Country and upon the coasts thereof": A letter in the family papers of Sir Henry Salusbury, drafted by Richard Whitbourne (?)}

Ryan Lewis, Peter E. Pope," and Tor Fosnas

A copy of a letter addressed "to the right honourable Charles, Earle of Nottingham" is preserved in a manuscript collection in the library of Christ Church College, Oxford. ${ }^{1}$ The subheading of the letter makes the general theme of the document clear: "it relates to Newfoundland." Both the substance and author of the letter are of importance with respect to early English settlement of Newfoundland and Canadian legal history.

The letter, one of the few manuscripts in the collection that is not dated, must have been written before 1619, as "Charles, Earle of Nottingham," to whom it is addressed, is Charles Howard, of Effingham, the Lord High Admiral of England, who served from 1585 until 1619. In addition to being undated, the letter is also unsigned, indicating that it is a copy of a sent letter. But the author offers an important clue to his identity by making reference to having taken "a voyage this last summer

Peter E. Pope passed away on 4 April 2017 at the age of 70. 
to Newfoundland."2 As we will see, the author is almost certainly Sir Richard Whitbourne of Exmouth, Devonshire, merchant, mariner, and early visitor and promoter of settlement in Newfoundland.

In 1620, Whitbourne published the first edition of his treatise on Newfoundland, entitled Discourse and Discovery of Nerwfoundland. ${ }^{3}$ In his book, Whitbourne describes his first visit to Newfoundland as a young man in 1579, his eyewitness account of Humphrey Gilbert's voyage to the island in 1583 , and his numerous visits to Newfoundland over the following decades. He notes that early Newfoundland was inhabited each summer by fishing crews who took up temporary residence along the rocky coast to prepare their catches for the European market. The natural environment suffered from the influx of thousands of fishermen, as forests were slowly destroyed by burning or rinding [removing the bark], and ballast began to fill up the harbour bottoms. Occasionally, fishermen came into conflict over the theft or destruction of fishing gear and other property. In 1611, John Guy, the governor of the first English plantation on the island, created a series of laws that were intended to address the abuses committed in the onshore fishery. The abuses Guy noted included theft and destruction of fishing nets, bait, boats, flakes, stages, and huts, the destruction of the forests, and the unregulated dumping of ballast, but Guy's laws were not enforced. In his Discourse, Whitbourne includes his own list of abuses, which he evidently compiled during his numerous visits to Newfoundland. He also refers to an appointment by the Admiralty in 1615, which gave him the power to convene courts there. At the turn of the seventeenth century, the Lord High Admiral had the power to appoint judges in the High Court of Admiralty in London. In the later seventeenth century, when a system of vice-admiralty courts developed for ports like Exeter and Boston, appointment became more complex. Whitbourne's was an early appointment for a court convened outside of London; the Lord High Admiral seems to have given him the power to empanel juries in Newfoundland in an attempt to address abuses in the fishery. ${ }^{4}$ The passage in the undated and unsigned manuscript referencing a "voyage this last summer to Newfoundland 
for the reformation of abuses committed in that Country and upon the coasts thereof" appears to refer to this event and, if so, is convincing proof that Whitbourne drafted the letter.

Whitbourne was known to Nottingham, and as he tells us in his Discourse he received letters of recommendation in the past from the Admiralty, most notably for his naval service against the Spanish Armada, in $1588 .{ }^{5}$ The legal proceedings mentioned by Whitbourne were the first Admiralty courts held outside of England, and most likely they were the reason for the voyage mentioned in the letter. Whitbourne travelled to Newfoundland in the first half of 1615, so the letter would have been written after the summer of 1615, perhaps in the later part of 1615 or in 1616 . This was about three years before the Earl of Nottingham stepped down from his post as Lord High Admiral. The main purpose of the letter seems to be to make an appeal to Nottingham to do more to rein in the abuses in the fishery, but also to encourage settlement in Newfoundland. Whitbourne believed that the fishery could coexist with settlement, a view that was not shared by all who later followed him to Newfoundland. He was motivated to bring a measure of order to the fishery, so motivated that he self-financed his officially authorized voyage to Newfoundland in 1615. Also, in 161516 , when the letter in question was likely written, Whitbourne was in need of a patron, so the letter is also a subtle request to the Lord High Admiral for further employment. If Whitbourne's letter received a reply, it has not yet been found.

Whitbourne returned to Newfoundland soon after he would have written this letter, but this time he was sponsored by a Welsh academic named Sir William Vaughan. In 1616 Vaughan had purchased land in Newfoundland from the London and Bristol Company, and in 1617 he sent a group of Welsh settlers to Newfoundland. Vaughan appointed Whitbourne as governor of the colony, and Whitbourne arrived in Newfoundland the following year. ${ }^{6}$ Vaughan had first contacted Whitbourne in 1617, after Whitbourne returned from a fishing expedition that took him to Newfoundland, Lisbon, and back to Britain. ${ }^{7}$ It is unclear how the two were introduced, perhaps through contacts 
in the London and Bristol Company. According to Whitbourne, he agreed to finance the expedition with Vaughan and some others, and set sail for Newfoundland in 1618 to serve as governor to the settlers who had arrived the previous year. ${ }^{8}$ He lost one of the two ships in his flotilla to pirates, and says that when he arrived in Vaughan's colony he discovered that the settlers had done nothing to set up their plantation. Instead, they had only sheltered in fishermen's huts over the long, cold winter, and their lack of activity demonstrated to Whitbourne that most of them were not settler material. Whitbourne sent all but six home, and moved the remaining colonists to Renews. ${ }^{9}$ Whitbourne says that Vaughan called them all home again soon after, and the plantation came to an end. ${ }^{10}$ At this point Whitbourne and Vaughan broke off their association.

Whitbourne published his Discourse about two years later, and between 1622 and 1626 he worked as an advisor for Henry Carey, Lord Falkland, as Carey made plans to establish a colony in Newfoundland. Meanwhile, Vaughan continued to promote his idea of establishing a plantation in Newfoundland, as Whitbourne's book states that Vaughan was "willing to entertain such as will be adventurers with him upon fit conditions." ${ }^{11}$ At about this time, Vaughan sold off part of his holdings in Newfoundland to two other investors, Lord Falkland and Lord Baltimore. He also attempted to attract his brother-inlaw, Sir Henry Salusbury, into purchasing land in Newfoundland, along "with some other gentlemen of North Wales." 12

The letter in question from Christ Church College is in a manuscript collection associated almost entirely with Sir John Salusbury. The collection includes medical recipes, letters, and a series of poems, some in English and some in Welsh, written by various contemporaries of Sir John. Sir John and his immediate descendants did not attend Christ Church, so it is not entirely clear how these documents found their way into the college library collection. ${ }^{13}$ However, along with the Salusbury manuscript collection at the National Library of Wales, the Christ Church documents are one of the best-known collections of Salusbury papers. ${ }^{14}$ 
Sir Henry Salusbury inherited the family estate at Lleweni in north Wales when his father, Sir John, died in 1612, and it was probably during Sir Henry's tenure that Whitbourne's letter was included with the family papers. It is difficult to say when Sir Henry's interest in Whitbourne and colonization in Newfoundland began, or when he acquired the letter. Both Sir Henry and his father were poets, and one of Sir Henry's surviving early poems is a short verse celebrating Columbus's American discoveries, entitled "Upon St. Christopher Columba."15 America, it would seem, was on his mind. Salusbury or his father may also have made some small investments in world trade, for they evidently purchased non-native cedar and pine seeds or saplings, and planted them in the extensive gardens at Lleweni. ${ }^{16}$ But when Sir Henry inherited the estate in 1612, it was deeply in debt and it took several years to consolidate his holdings. In 1617, he married Elizabeth, William Vaughan's half-sister. If his interest in Newfoundland had not developed earlier, he no doubt began to develop an interest at this juncture, even though he was not in a financial position to invest in Vaughan's colony. By 1625 his finances appear to have recovered, for he leased an estate in Ireland, thereby joining a growing list of Welsh gentry who were establishing themselves on the west side of the Irish Sea. ${ }^{17}$ In the later 1620s, he responded to Vaughan's requests to establish himself in Newfoundland and leased land from Lord Falkland. According to Salusbury's grant, dated from 1628, he purchased two lots of land, one centred on Fermeuse Harbour, the other on Trinity Bay. ${ }^{18}$ Salusbury's name appears on a petition, probably from 1628 , that is addressed to the new Lord High Admiral, the Duke of Buckingham and is co-signed by William Vaughan, Vaughan's father Walter and youngest brother Henry, and several others. The petition is intended to bring to the attention of Buckingham, and by extension the new King, Charles I, the importance of promoting settlement in Newfoundland. ${ }^{19} \mathrm{He}$ was intent on developing the land and sending settlers, as his name is also associated with a document entitled Advice on Planting in Newfoundland, given to Sir Henry Salusbury. ${ }^{20}$ That informative document is an "estimate for the victuals for eight persons for a yeare to inhabit in New found lande," and 
was drawn up for Salusbury by John Poyntz, a settler in Vaughan's earlier plantation. ${ }^{21}$ It seems that Salusbury was committed to establishing a settlement in Newfoundland, but his plans died with him in 1632.

We are left with the copy of the letter addressed to Lord High Admiral Howard and the question of why it appears in Salusbury's manuscripts. Whether Salusbury and Whitbourne knew each other is unclear, but Salusbury could easily have received the letter from Vaughan, Falkland, or from another member of the London and Bristol Company. The letter was most likely written in 1615-16, but it probably did not receive a reply. Howard by that time was almost 80 and was increasingly distracted by his own rivalry at court with George Villiers, the Duke of Buckingham. Shortly after, in 1619, Howard was investigated for corruption and was pushed aside by Buckingham. Whitbourne's report may have been lost in the shuffle. Whitbourne himself suggests in the1622 edition of his Discourse that the results of his commission from the Office of the Lord Admiral and his activities in Newfoundland on behalf of the Admiralty had been overlooked, or as he says, "overslipt ever since." 22 Howard's successor, the Duke of Buckingham, may well have dismissed the older man's files. Somehow, a copy was preserved in the Salusbury papers, most likely because the letter described Newfoundland.

By the 1620s, Henry Salusbury was actively gathering background information about settlement in Newfoundland, as the document he obtained from John Poyntz suggests. He may have been given the letter or obtained it because of its brief description of Newfoundland. However, if he had been looking for a description of Newfoundland in the 1620s, he could have turned to Whitbourne's book, by then available. If he acquired the letter for information purposes, then it would seem that he did so before Whitbourne's book was available. This suggests that he may have been entertaining the idea of investing in a plantation in Newfoundland at an earlier date, and obtained the letter soon after it was written.

The identification of this letter as Richard Whitbourne's is important, even if he covers the same ground in his Discourse of 1620. There, 
also, he claims an official Admiralty appointment in 1615, to convene a court in Newfoundland - but, prior to the identification of his letter, we had no independent evidence of this event. Because the letter addresses the Lord High Admiral, it offers strong support for Whitbourne's claim, since that senior official had the authority to appoint judges to the Court of Admiralty and Whitbourne could not have hoped to fool him on the issue. Such episodes in Whitbourne's career are not simply of biographical interest. He was, in many ways, Newfoundland's Champlain: a major figure in the early European exploitation of North America, with the wit, the education, and the connections to publish a detailed description of the economic geography of a whole region, together with a convincing defence of settlement. Whitbourne's accomplishments are significant chapters in North Atlantic history.

In the letter, Whitbourne touches on several important issues raised later in his Discourse. As with his later publication, the letter reflects his positive view of Newfoundland's potential. Typical of early seasonal European visitors to the island, he underestimates the possible severity of the climate. He gives a middle-of-the-road estimate of the size of the British fishery at the time (5,000 men in 250 ships), and he stresses the presence of French and Portuguese competitors. The mention of the latter in 1615 is a little surprising, other indications being that the Portuguese fishery declined rapidly after 1588 or so. Whitbourne's Discourse is also full of such detail, posing serious questions for the historian or archaeologist. The letter clearly reflects the policy positions that Whitbourne would promote in his publication. He was already a booster of the Newfoundland fishery, both as a commercial strategy and as a transatlantic strategy. At the same time, he was a proponent of Newfoundland settlement and a relatively realistic one at that, understanding that initial colonies needed subsidy. While it is interesting to see how the letter prefigures the major themes of the Discourse, its major significance surely remains its confirmation that Whitbourne held a court in Newfoundland in 1615.

Newfoundlanders may have some trouble parsing the significance of that court, since a confusing folk history about fishing admirals 
obscures the events of $1615 .{ }^{23}$ In popular memory, Whitbourne was a fishing admiral. He may have been that, for one pleasant early seventeenth-century summer or another, if he was the first fishing master to arrive in a Newfoundland harbour and therefore had the right to first choice of fishing room and the duty to settle disputes between other fishing crews subsequently arriving. In 1615, however, he was not a fishing admiral, but held a temporary appointment to convene what was, in effect, an early version of a vice-admiralty court. Nor was Whitbourne an officer in the navy at that time, let alone an admiral. His career in Newfoundland long predated the "rule of the admirals" - the Royal Navy's administration of the island, which took shape only late in the seventeenth century to flourish in the eighteenth. ${ }^{24}$ Whitbourne's court in Newfoundland in 1615 seems to have been, in its time, sui generis. His was not only the first British admiralty court in the New World but also the first European court in Canada, so it should be of interest not only to Newfoundlanders but also to students of British and Canadian legal history.

\section{DOCUMENT}

Copy of a Letter to the right honourable Charles Earle of Nottingham Baron Howard of Effingham, etc. It Relates to Newfoundland ${ }^{25}$

To the right honourable Charles Earle of Nottingham Baron Howard of Effingham Knight of the noble order of the garter one of his Majesty's most honourable Privy Council Lord High Admiral of England. My honourable good Lord

It pleased you out of noble disposition upon some favourable reports above my deserving, made of me by some righteous persons to employ my poor service in a voyage this last summer to Newfoundland for the reformation of abuses committed in that Country and upon the coasts thereof, by some people there trading for fish and others of our nation, to effectuate more readily which I had my honorable 
Commission, giving a large and full Authority in so weighty a matter as by the commission proposed; to this short discourse more plainly of Newfoundland.

What pains I Tooke there; and what course I held to bring the people to a conformity and good conclusion, is here summarily in second presentments of Juries by which those impaneled set down at the [blank] of the relation of the voyages upon mine own purse went the charges which hath been very dear to me as it may be well understood; and all the account I advanced unto Your Lordship of my travel, is that which Harbors after long and leafsome ${ }^{26}$ voyages when they enterime $[?]^{27}$ themselves, present unto Your Majesty being nothing else but a bundle of papers to no great purpose.

My passing of this compendious relation Your Lordship shall not only find what I have herein done, but from hence may a supposition or reflection be made so what further in so high and material a business may be done to the general good of the whole Kingdome, if by the King's Royall Authority leave may be given not only nobly to set forward; but also resolutely to go through with it.

Strange it is in my poor judgment that men should recoil in a work so good for it is known that divers worthy Gentlemen, and others that have seen the Country have all at their coming home bestowed Praise and Worthy Commendations upon it, yet none other than it deserves, and those hearty wishes that it might be so inhabited and a plantation there settled, which yet notwithstanding to the great grief of many goes by but slowly forward: What should [we] therein fear [?] If honor and profit be the principal master at every end in this world for temporal blessings shoot [?]; why then do we bend our whole endeavor and aim thence towards this Newfoundland where are both to be had; What is there in most Countries for any man's use which there is not to be gotten? What is there wanting in that place which man can do? Shall I speak [as] one of [the] wisest praisers of the Country and in that shut up all the rest? Give me then leave to say this much to your Lordships that the Newfoundland is environed round with the sea, a climate so wholesome for mans' $[$ sic $]$ health that I think 
few parts of the world are comparable to it, the quality [thereof] is an instance, that last year when there lay 250 English ships 5000 [deletion] Persons at least in them, besides many sails both of French and Portuguese, who all came thither to employ their ships and their fishers in fishing, And that I sailed to be free amongst them about 150 leagues, yet could I not see nor heard of any man or boy in either of these nations that died during the whole voyage nor not so much as anyone to go sick. How excellent a plantation were this therefore my good Lord to be inhabited by Christians, as to whence goes the plantation as it now stands, If I may, with your Lordship's pardon, freely deliver mine opinion I think it had no sound nor settled foundation, neither as it is, can it subsist or grow without more and more substantial props to be added to support it.

Many honorable and worthy persons who at first were hot in pursuit of so noble and honorable a business, it is to be doubted unless they be worthily seconded by others that they will both repent them of their charge already laid out and also wax could and weary in disbursing more; and so may the country by the remissness of our nation be left or taken from them and lost to the spoil or usurpation of some other Prince, whose subjects will reap the harvest of our labour. Therefore by your honourable personage upon so weighty an importance to his Majesty. Your Lordship would be pleased to make known to His Highness the honour benefit and enlargement of this dominion; by exchanges [custom] by mariners and shipping etc. besides infinite commodities to his people which all arise out of this Country it is no question to be made but for so general a good his wisdom would both allow of so necessary a work and it might be by your Lordship's assistance and Authority be moved and go forward, But if neither the King's Majesty will hearken after a project of this nature; and that Yr. Lordship be carried in opinion from it, yet I beseech his highness to pardon this my presumption which out of my soul's devotion and service to my sovereign and my Country I tender on my knees and most humbly entreat Your Lordship to call my boldness an honest zeal for I have desired rather to bear the burthen of poverty then of the rich. 


\section{Notes}

1 Carleton Brown, ed., Poems by Sir John Salusbury and Robert Chester (London: Early English Text Society, 1914), xxix.

$2 \quad$ Christ Church MS 183, fol. 21.

3 Richard Whitbourne, $A$ Discourse and Discovery of Nerwfoundland, in Gillian Cell, ed., Newfoundland Discovered: English Attempts at Colonization 1610-1630 (London: The Hakluyt Society, 1982), 100-206. The edition Cell uses is Whitbourne's second edition, but differences with the first edition are collated in footnotes.

4 Ibid., 159-61,114. See also J. Derek Green, "Sir Richard Whitbourne and the Rule of Law in Early Colonial Newfoundland: The First Court of Vice Admiralty in the New World," in Melvin Baker, Christopher Curran, and J. Derek Green, eds., Discourse and Discovery: Sir Richard Whitbourne Quatercentennial Symposium 1615-2015 and Beyond (St. John's: Law Society of Newfoundland and Labrador, 2017), 17-26.

5 Cell, Newfoundland Discovered, 111.

6 See William Vaughan, The Golden Fleece Part III (London, 1625); Cell, Nerwfoundland Discovered, 24. See also A.G. Prys-Jones, "Poor Cambriol's Lord: Sir William Vaughan (1577-1641) Colonial Pioneer, Writer and Agricultural Reformer," The Carmarthenshire Historian (1961): 28-34.

7 Cell, Newfoundland Discovered, 114.

8 Ibid., 24, 114-15.

9 Ibid., 22-23, 134-35; Peter Pope, Fish Into Wine: The Nerufoundland Plantation in the Seventeenth Century (Chapel Hill: University of North Carolina Press, 2004), 52.

10 Cell, Newfoundland Discovered, 13, 24-25, 106 n. 6; cf. William Gilbert, "An Orpheus in Newfoundland? Sir William Vaughan, John Oldnixon, D.W. Prowse and Trepassey," Newfoundland Quarterly 109, 4 (2017): 38-45.

11 Cell, Nerwfoundland Discovered, 106.

12 William Vaughan, Newlander's Cure (London, 1630).

13 At least one later descendant of the Salusburys attended Christ Church in the nineteenth century, which may explain the connection. 
14 Poems by the Salusburys of Lleweni, National Library of Wales (NLW), MS 5390D.

15 Ibid.

16 R.T. Gunther, Early British Botanists and Their Gardens (Oxford: Oxford University Press, 1922), 307 n. 1. Perhaps these trees came from North America. This would be consistent with the activities of some of Salusbury's landowning contemporaries, such as Thomas Bowen from Pembrokeshire, who had sailors bring "fir trees" back to Wales from "the Newfoundland," or Thomas Hamner of Flintshire, who planted non-native conifers in his gardens at Bettisfield. See R.C., An Old Thrift Wherein is declared the manner of planting, preserving, and husbanding of young trees of diverse kinds for timber and fuel (1612), 8; Thomas Hamner, Garden Books of Sir Thomas Hamner (1659). See also William Linnard, Welsh Woods and Forests: History and Utilization (Cardiff: National Museum of Wales, 1982), 64.

17 Rhys Morgan, The Welsh and the Shaping of Early Modern Ireland 1558-1641 (Woodbridge, Suffolk, UK: Boydell Press, 2014), 121-22.

18 Cell, Newfoundland Discovered, 245-46, Gillian Cell, English Enterprise in Newfoundland 1577-1660 (Toronto: University of Toronto Press, 1969), 91.

19 NLW, MS 5390D, in Cell, Newfoundland Discovered, 283-84.

20 Cell, Newfoundland Discovered, 246-49.

21 Ibid., 246. See also Robert Hayman, Quodlibets, Lately Come Over from New Britaniola, Old Newfoundland. Book II (London, 1628), 32. Poyntz was likely a member of the Poyntz family from Iron Acton, Gloucestershire. The Poyntz family held mining interests in Kidwelly, in Carmarthenshire, which may explain John Poyntz's association with Vaughan. See H.A. Lloyd, The Gentry of South Wales, 1540-1640 (Cardiff: University of Wales Press, 1968), 81, 83.

22 Cell, Newfoundland Discovered, 114.

23 Peter E. Pope, "The Admiral System: Customary Law and Conflict Management, 1500-1800,"in Baker, Curran, and Green, eds., Discourse and Discovery: Sir Richard Whitbourne Quatercentennial Symposium, 27-38.

24 Jerry Bannister, The Rule of the Admirals: Laws, Customs, and Naval Government in Newfoundland, 1699-1832 (Toronto: University of Toronto Press), 2003. 
25 Christ Church MSS 183 folio 21; Brown, ed., Poems by Sir John Salusbury and Robert Chester, xxix.

26 leesome $=$ pleasant

27 entermete $=$ to concern or occupy oneself with something. 